\section{Preliminary Research Concerning the Association Between the Genotypes at the Kappa-Caseine Locus and Milk Production Traits in Cattle}

\author{
Augustin Vlaic - Daniel Ciobanu - Teofil Oroian \\ University of Agricultural Sciences and Veterinary Medicine,
} Cluj-Napoca

\section{SUMMARY}

The genotypes for kappa-casein locus were established using PCR-RFLP. Genome DNA for PCR amplification was isolated from hair roots in cows (30 Schwitz individuals), and from frozen semen in bulls (42 bulls of different breeds).

A higher frequency of the $B$ allele in Schwitz $\left(p_{A}=0.45\right.$ and $q_{B}$ $=0.55$ in cows and $p_{A}=0.25$ and $q_{B}=0.75$ in bulls), and a higher frequency of the A allele in bulls belonging to different breeds ( $p_{A}$ $=0.61$ and $q_{B}=0.39$ in Deutsch Simmental, $p_{A}=0.84$ and $q_{B}=$ 0.16 in Romanian Simmental; $p_{A}=1.00$ and $q_{B}=0.00$ in Holstein, and $p_{A}=0.67$ and $q_{B}=0.33$ in Pinzgauer) were estimated. The associations between the genotypes and alleles determined at the kappa-casein locus and milk production were tested. They emphasized significant associations only for milk and milk fat quantity, in advantage of individual carriers of the $B$ allele in homozygous and heterozygous states.

\section{INTRODUCTION}

The use of genetic marker-assisted selection at DNA level (MAS) is increasing in cattle, swine and sheep breeding programs from countries with advanced animal husbandry, due to the fact that it permits early decision on the use or exclusion of an animal for reproduction and, at the same time, substantial genetic progress for the traits associated with these markers.

Of genetic markers discovered in cattle, some milk proteins (kappa-casein and $\beta$-lactoglobuline) that are regulated by a pair of major genes (A and B) with co-dominant transmission, are used for selection.

A majority of worldwide research (Bulla et al., 1995; Eenennaam and Medrano, 1991; Fesus, 1995; Fesus and Zsolnai, 1997; Futerova et al., 1999; Medrano and Aquilar-Cordova, 1990; Stevanovic et al., 2000; Vlaic et al., 2000) results show that the B allele of kappa-casein in cattle is correlated with a higher level of milk protein, compared to the A allele of kappa-casein. The BB genotype of kappa-casein in cattle was associated with the production of a milk with superior processing properties. The use of cow milk with $\mathrm{BB}$ genotype of kappa casein in cheese production results in shorter milk coagulation time, a more dense coagula due to the smaller mycelium and a higher cheese production compared to the milk from cows with AA genotype of kappa-casein (Eenennaam and Medrano, 1991).

\section{MATERIAL AND METHOD}

The genotypes for kappa-casein locus were established using PCR-RFLP, for 30 Schwitz cows, and 42 bulls belonging to the following breeds: Schwitz, Deutsche Simmental, Romanian Simmental, Black and White (Romanian type), Red-Holstein, Pinzgauer and Red Holstein x Romanian Simmental hybrids. The genome DNA necessary for PCR amplification was isolated from hair roots in cows, and from frozen semen in bulls.

DNA amplification using kappa-casein specific primers in cattle was realized using PCR, in the Molecular Genetics Laboratory of Cluj-Napoca University of Agricultural Sciences and Veterinary Medicine (using the method described by Medrano and Aquilar-Cordova, 1990). The amplification product was digested with restriction enzyme Hinf I, and the resulted restriction fragments were submitted to electrophoretic migration in agarose gel (2.5-3\%) and emphasized using an UV transiluminator.

The genotypes of the analysed individuals at kappa-casein locus were established using the restriction fragments emphasized in gel (Figure 1).

Figure 1: The genotypes at kappa-casein locus

\begin{tabular}{|c|c|c|c|c|}
\hline \multirow{2}{*}{$\begin{array}{c}\text { Nr. base } \\
\text { pairs } \\
\text { (bp) }\end{array}$} & \multicolumn{3}{|c|}{ GENOTYPES } & \multirow{2}{*}{$\begin{array}{c}\text { Undigested } \\
\text { amplification } \\
\text { product }\end{array}$} \\
\hline & AA & AB & BB & \\
\hline 350 & & & & \\
\hline 266 & & & & \\
\hline $132 / 134$ & & & & \\
\hline
\end{tabular}

The gene and genotypes frequency at the kappacasein locus both in cows and bulls were estimated. The associations between the quantitative and qualitative traits of milk production and genotypes, were tested using Student test in cows, and Fisher test in bulls.

\section{RESULTS AND DISCUSSION}

The genetic structure at kappa-casein locus for both cows and bulls is presented in Tables 1 and 2 . Our researches (Tables 1, 2) and also literature show a higher frequency of the $\mathrm{B}$ allele in Schwits, compared to the A allele $\left(\mathrm{p}_{\mathrm{A}}=0.38\right.$ and $\mathrm{q}_{\mathrm{B}}=0.62$, Kiddy et al., 1968; $\mathrm{p}_{\mathrm{A}}=0.41$ and $\mathrm{q}_{\mathrm{B}}=0.59$, Li and Gaunt, 1972; $\mathrm{p}_{\mathrm{A}}=0.33$ and $\mathrm{q}_{\mathrm{B}}=0.67$, Eenennaam and Medrano, 1991 in Brown Swiss).

A majority of research (Table 3) shows a higher frequency of the A allele compared to the B allele in Holstein $\left(\mathrm{p}_{\mathrm{A}}=0.82\right.$ and $\mathrm{q}_{\mathrm{B}}=0.18$, Eenennaam and 
Medrano, 1991; $\mathrm{p}_{\mathrm{A}}=0.89$ and $\mathrm{q}_{\mathrm{B}}=0.11$, Medrano and Aquilar-Cordova, 1990).

The average values of characters, located on three genotypes of kappa-casein, the differences between the average values and the significance of these differences tested using the Student test are presented in Table 4. The differences between the average values are advantageous to individuals with the $B$ allele in homozygous (BB) or heterozygous (AB) state in all analyzed traits (IInd lactation), significant differences are recorded only for fat quantity from milk.

The associations between the alleles from the kappa-casein locus and the bulls breeding value estimated using progeny test (fat quantity, fat percent, protein quantity) are presented in Table 4.

SEMTEST Baia-Mare possesses 42 bulls, 22 were imported from Germany and the other 20 were from domestic stock. A number of 33 bulls from the total of 42 were tested using a progeny test for milk production traits. The number of bulls' daughters are variable. The genotype at kappa-casein locus for bulls' daughters was not established.
The association between the B allele of kappacasein and the traits of milk production, determined for bulls' daughters from SEMTEST Baia-Mare was tested using variance analysis (Harvey program). A significant association between the $\mathrm{B}$ allele and the results of bulls tested for fat quantity from milk using a progeny test was found. The fat quantity from milk is the main cattle selection criteria in Romania. The others analysed traits (fat percent from milk, protein quantity and breeding value) represent secondary selection criteria and often neglected in breeding. The result of associations was statistically insignificant for these traits (Table 5).

Table 1: The genetic structure at the kappa-casein locus in Schwitz cows

\begin{tabular}{|c|r|r|c|}
\hline Genotype & $\begin{array}{c}\text { Number of } \\
\text { individuals }\end{array}$ & \multicolumn{1}{|c|}{$\begin{array}{c}\text { Genotype } \\
\text { frequency }\end{array}$} & $\begin{array}{c}\text { Allele } \\
\text { frequency }\end{array}$ \\
\hline AA & 6 & 0,20 & \multirow{2}{*}{$\mathrm{p}_{\mathrm{A}}=0,45$} \\
\cline { 1 - 2 } $\mathrm{AB}$ & 15 & 0,50 & \\
\cline { 1 - 2 } $\mathrm{BB}$ & 9 & 0,30 & \multirow{2}{*}{$\mathrm{q}_{\mathrm{B}}=0,55$} \\
\hline
\end{tabular}

Table 2: The genetic structure at the kappa-casein locus in bulls from SEMTEST Baia-Mare

\begin{tabular}{|c|c|c|c|c|c|c|}
\hline \multirow[t]{2}{*}{ Breed } & \multirow{2}{*}{$\begin{array}{l}\text { Number of } \\
\text { individuals }\end{array}$} & \multicolumn{3}{|c|}{ Genotype frequency } & \multicolumn{2}{|c|}{ Gene frequency } \\
\hline & & AA & AB & BB & $\mathbf{p}_{\mathrm{A}}$ & $\mathbf{q}_{\mathbf{B}}$ \\
\hline Schwitz & 14 & 0.07 & 0.36 & 0.57 & 0.25 & 0.75 \\
\hline Deutsche Simmental (Fleckvieh) & 9 & 0.33 & 0.56 & 0.11 & 0.61 & 0.39 \\
\hline Romanian Simmental & 5 & 0.67 & 0.33 & 0.00 & 0.84 & 0.16 \\
\hline Black and White (Romanian type) & 3 & 1.00 & 0.00 & 0.00 & 1.00 & 0.00 \\
\hline Pinzgauer & 1 & 0.3 & 0.67 & 0.00 & 0.67 & 0.33 \\
\hline Red-Holstein & 4 & 1.00 & 0.00 & 0.00 & 1.00 & 0.00 \\
\hline Red-Holstein x Romanian Simmental hybrids & & 0.00 & 1.00 & 0.00 & 0.50 & 0.50 \\
\hline
\end{tabular}

Table 3: The allele frequency at the kappa-casein locus (data from literature)

\begin{tabular}{|c|c|c|c|c|}
\hline \multirow[t]{2}{*}{ Breed } & \multicolumn{2}{|c|}{ Frequency of genes } & \multirow[t]{2}{*}{ Country } & \multirow[t]{2}{*}{ Authors } \\
\hline & $\mathbf{p}_{\mathrm{A}}$ & $\mathbf{q}_{\mathrm{B}}$ & & \\
\hline \multirow{8}{*}{ Holstein } & 0.68 & 0.32 & Australia & $\begin{array}{l}\text { McLean et al., } 1984 \text { quoted by } \\
\text { Eanennaam and Medrano, } 1991\end{array}$ \\
\hline & 0.75 & 0.25 & USA & Li and Gaunt, 1972 \\
\hline & 0.80 & 0.20 & USA & Kiddy et al., 1968 \\
\hline & 0.89 & 0.11 & USA & Medrano et al., 1990 \\
\hline & 0.82 & 0.18 & USA & Eenennaam and Medrano, 1991 \\
\hline & 0.73 & 0.27 & Italy & $\begin{array}{l}\text { Aleandri et al., } 1990 \text { quoted by } \\
\text { Eenennaam and Medrano, } 1991\end{array}$ \\
\hline & 0.79 & 0.21 & Slovakia & Bulla et al., 1995 \\
\hline & 0.84 & 0.16 & Hungary & Fesus et al., 1997 \\
\hline Holstein (Deutsch type) & 0.78 & 0.22 & Slovakia & Bulla et al., 1995 \\
\hline \multirow{3}{*}{ Brown Swiss } & 0.38 & 0.62 & USA & Kiddy et al., 1968 \\
\hline & 0.41 & 0.59 & USA & Li and Gaunt, 1972 \\
\hline & 0.33 & 0.67 & USA & Eeneennam and Medrano, 1991 \\
\hline Simmental & 0.44 & 0.56 & Slovakia & Bulla et al., 1995 \\
\hline Pinzgauer & 0.88 & 0.22 & Slovakia & Bulla et al., 1995 \\
\hline
\end{tabular}


Table 4: The association of the kappa-casein genotypes with milk production traits in Schwitz cows (the IInd lactation)

\begin{tabular}{|c|c|c|c|c|c|c|}
\hline Trait & $\begin{array}{c}\text { Compared } \\
\text { genotypes }\end{array}$ & Average values & Differenced & $\mathbf{s}_{\mathrm{d}}$ & $\mathbf{t}$ & Significance \\
\hline \multirow{3}{*}{$\begin{array}{c}\text { Lactation } \\
\text { length } \\
\text { (days) }\end{array}$} & AA - BB & $267,75-279,00$ & $-11,25$ & 13,17 & $-0,85$ & $\mathrm{~ns}$ \\
\hline & $\mathrm{AA}-\mathrm{AB}$ & $267,75-292,14$ & $-24,39$ & 11,35 & $-2,14$ & $\mathrm{~ns}$ \\
\hline & $\mathrm{BB}-\mathrm{AB}$ & $279,00-292,14$ & $-13,14$ & 13,50 & $-0,97$ & $\mathrm{~ns}$ \\
\hline \multirow{3}{*}{$\begin{array}{c}\text { Milk } \\
\text { quantity } \\
(\mathrm{kg})\end{array}$} & $\mathrm{AA}-\mathrm{BB}$ & $2421,50-3160,80$ & $-739,30$ & 327,96 & $-2,25$ & ns \\
\hline & $\mathrm{AA}-\mathrm{AB}$ & $2421,50-3328,43$ & $-906,93$ & 342,86 & $-2,64$ & $\mathrm{x}$ \\
\hline & $\mathrm{BB}-\mathrm{AB}$ & $3160,80-3328,43$ & $-167,63$ & 452,13 & $-0,37$ & $\mathrm{~ns}$ \\
\hline \multirow{3}{*}{$\begin{array}{c}\text { Fat } \\
\text { percent } \\
(\%) \\
\end{array}$} & $\mathrm{AA}-\mathrm{BB}$ & $3,83-3,81$ & $+0,02$ & 0,11 & $+0,12$ & ns \\
\hline & $\mathrm{AA}-\mathrm{AB}$ & $3,83-3,87$ & $-0,04$ & 0,09 & $-0,45$ & ns \\
\hline & $\mathrm{BB}-\mathrm{AB}$ & $3,81-3,87$ & $-0,06$ & 1,10 & $-0,57$ & $\mathrm{~ns}$ \\
\hline \multirow{3}{*}{$\begin{array}{c}\text { Fat } \\
\text { quantity } \\
(\mathrm{kg})\end{array}$} & $\mathrm{AA}-\mathrm{BB}$ & $92,62-120,50$ & $-27,88$ & 3,84 & $-7,25$ & $\mathrm{xxx}$ \\
\hline & $\mathrm{AA}-\mathrm{AB}$ & $92,62-129,78$ & $-37,16$ & 4,12 & $-9,01$ & $\mathrm{xxx}$ \\
\hline & $\mathrm{BB}-\mathrm{AB}$ & $120,50-129,78$ & $-9,28$ & 5,09 & $-1,82$ & $\mathrm{~ns}$ \\
\hline
\end{tabular}

$\mathrm{ns}=\mathrm{P}>0,05 ; \mathrm{x}=\mathrm{P}<0,05 ; \mathrm{xxx}=\mathrm{P}<0,001$

Table 5: Testing of the B allele from kappa-casein effect on bulls' breeding value using a progeny test in bulls from SEMTEST Baia-Mare

\begin{tabular}{|c|c|c|c|c|c|c|}
\hline Trait & Variation source & d.f. & Sum of squares & $\begin{array}{l}\text { Mean of } \\
\text { squares }\end{array}$ & $\mathbf{F}$ & $\begin{array}{c}\text { Probability and } \\
\text { signification }\end{array}$ \\
\hline \multirow{5}{*}{$\begin{array}{c}\text { Fat } \\
\text { quantity } \\
(\mathrm{kg})\end{array}$} & Total & 32 & 7810.78 & & & \\
\hline & Total treatments & 3 & 2017.50 & 675.83 & 3.39 & 0.03 \\
\hline & MU-YM & 1 & 43.80 & 43.79 & 0.22 & 0.64 \\
\hline & k-CN B allele effect & 2 & 2027.50 & 1013.75 & 5.08 & $0.05 *$ \\
\hline & Experimental error & 19 & 5783.28 & 199.42 & & \\
\hline \multirow{5}{*}{$\begin{array}{c}\text { Fat } \\
\text { percent } \\
(\%)\end{array}$} & Total & 32 & 16957.85 & & & \\
\hline & Total treatments & 3 & 2245.03 & 784.34 & 1.48 & 0.24 \\
\hline & MU-YM & 1 & 26.81 & 26.81 & 0.05 & 0.82 \\
\hline & k-CN B allele effect & 2 & 2245.03 & 1122.52 & 2.21 & $0.13 \mathrm{~ns}$ \\
\hline & Experimental error & 19 & 14712.81 & 507.34 & & \\
\hline \multirow{5}{*}{$\begin{array}{l}\text { Protein } \\
\text { quantity } \\
(\mathrm{kg})\end{array}$} & Total & 21 & 611.81 & & & \\
\hline & Total treatments & 3 & 18.57 & 6.19 & 0.19 & 0.90 \\
\hline & MU-YM & 1 & 0.37 & 0.37 & 0.01 & 0.92 \\
\hline & k-CN B allele effect & 2 & 18.57 & 9.29 & 0.28 & $0.76 \mathrm{~ns}$ \\
\hline & Experimental error & 18 & 593.24 & 32.96 & & \\
\hline
\end{tabular}

\section{CONCLUSIONS}

The B allele of kappa-casein in Schwitz has a higher frequency $(0.55)$ compared to A allele (0.45). Others researchers obtained the same results in different Schwitz populations.

The differences are in advantage of individuals with the B allele in homozygous or heterozygous state in all analysed traits (IInd lactation). Very significant differences are recorded only for fat quantity from milk.

Our results confirmed a link between the B allele of the kappa-casein and some traits of milk (fat quantity).
Selection using genetic markers established at DNA level, is a valuable technique that must also be implemented for cattle breeds in Romania.

A higher frequency of the B allele associated with a higher fat content in milk from the kappa-casein locus (0.75) and a lower frequency of the A allele (0.25), was found in Schwitz bulls and cows. A higher frequency of A allele (0.50-1.00) was recorded in bulls belonging to others breeds and RedHolstein x Romanian Siemental hybrids.

The selection of individuals with the $\mathrm{B}$ allele in homozygous and heterozygous state, and their use for reproduction is recommended. A milk with superior properties for cheese production can be obtained.

\section{REFERENCES}

Bulla, J.-Lazarevic, R.-Vasicek, D.-Chrenec, P.-Uhrin, P.Bauerova, M.-Podolanova, E.-Oberfrank, M. (1995): Aplication of the PCR genotyping of different cattle breeds for kappa-casein and $\beta$-lactoglobulin alleles. Biotehnologija $\mathrm{u}$ Stocarstu, 11. 3-6. 65-68.

Eenennaam, V.-Medrano, J. F. (1991): Differences in allelic proteic expression in the milk of heterozygous kappa-casein cows. Dairy Sci., 74. 1491.

Eenennaam, V.-Medrano, J. F. (1991): Milk Protein Polymorphisms in California Dairy Cattle. Dairy Sci., 74. 1730-1742.

Fesus, L. (1995): Molekuláris Genetikai Szelekciós Módszerek a 
Holstein-fríz esetén. Tejtermelési Tanácskozás, Debrecen, 6263.

Fesus, L.-Zsolnai, A. (1997): Use of Molecular Genetic Markers in Animal Breeding in Hungary. $I^{\text {st }}$ Yugoslav International Congress on Animal Husbandry, Biotechnologija u Stocarstvu, Beograd, 13. 3-4. 41-56.

Futerova, J.-Sablikova, L.-Kopecny, J.-Stipkova, M.-Jandurova, O. (1999): Association between $\beta$-lactoglobulin genotypes and its content in milk. Book of abstracts 5. 50 $0^{\text {th }}$ Annual Meeting of EAAP, Genetics section, Zürich, 63.

Kiddy, C. A.-McCann, R. F. E.-Thatcher, W. W. (1968): Gene frequencies in milk protein polymorphism in dairy cattle. Immunogenet., Lett., 5-150.

Li, H. F.-Gaunt, S. N. (1972): Study of genetic polymorphisms of milk $\beta$-lactoglobulin, $\alpha_{\mathrm{s} 1}$-casein, $\beta$-casein and $\mathrm{k}$-casein in five dairy breeds. Biochem.Genet., 6-9.
Medrano, J. F.-Aquilar-Cordova, E. (1990): Genotyping of bovine k-casein loci following DNA sequence amplification. Biotechnology, 8. 144-146.

Sablikova, L.-Jandurova, O.-Stipkova, M. (1999): Relationships between milk protein genotype and milk production traits in Jersey breed. Book of abstracts 5. 50 $0^{\text {th }}$ Annual Meeting of EAAP, Genetics section, Zurich, 63.

Stevanovic, M.-Stanojcic, S.-Djurovic, J.-Verbic, V. (2000): Molecular marker technologies and selection for the traits of economic interest. Biotechnology in Annimal Husbandry, 16. 1-2. 25-34.

Vlaic, A.-Oroian, T.-Handoca, E. (2000): Variantele genetice ale k-cazeinei determinate prin tehnica PCR-RFLP şi asocierea acestora cu însuşirile producției de lapte la rasa Brună. Rezumatele lucrărilor celui de al XXI-lea Simpozion Naţional de Genetică vegetală şi animală, Cluj-Napoca, 65-66. 